\title{
Late effects of antineoplastic therapy on the developing dentofacial complex
}

\author{
Balasubramanian Madhan, Gnanasekaran Arunprasad, Balasubramanian Krishnan
}

Department of Dentistry, Jawaharlal Institute of Postgraduate Medical Education and Research, Puducherry, India

\section{Correspondence to} Dr Balasubramanian Madhan, madhanb@hotmail.com

Accepted 20 March 2014
CrossMark

\section{To cite: Madhan $B$,} Arunprasad G, Krishnan B. BMJ Case Rep Published online: [please include Day Month Year] doi:10.1136/ bcr-2014-204438

\section{DESCRIPTION}

A 26-year-old man reported with the chief complaints of dry mouth, facial swelling and difficulty opening his mouth. His medical records indicated that he had been treated for nasopharyngeal squamous cell carcinoma when he was 10 years old. $\mathrm{He}$ had undergone two cycles of chemotherapy (cisplatin, 5-fluorouracil and vincristine) followed by 60 Gray of cobalt-60 beam therapy to the nasopharynx and bilateral cervical lymph nodes. After defaulting on follow-up for nearly 14 years, he presented with the following dental and maxillofacial features that are classically the late side-effects of antineoplastic therapy: ${ }^{1-3}$

- Xerostomia due to atrophy and fibrosis of the salivary glands.

- Trismus (figure 1) due to myofibrosis, loss of soft tissue flexibility, and hypomobility of the temporomandibular joint.

- Altered dental development including arrested development of teeth/roots, short, blunted or tapered roots, enlarged pulp chambers (taurodontism), microdontia and hypoplasia (figure 2). The patient's past dental history indicated that a few mobile teeth, probably with compromised periodontal support, had exfoliated spontaneously, resulting in partially edentulous arches.

- Features of osteoradionecrosis including suppuration, cortical destruction, sequestration and pathological fracture (figure 2). Clinically, these features presented as pain, an orofacial fistula in the left cheek with suppurative discharge, a $3 \times 3 \mathrm{~cm}$ soft swelling in the left pre-auricular region filled with pus (figure 3), and exposed necrotic bone in the left posterior alveolar region of the mandible with ulceration/necrosis of the overlying mucosa.

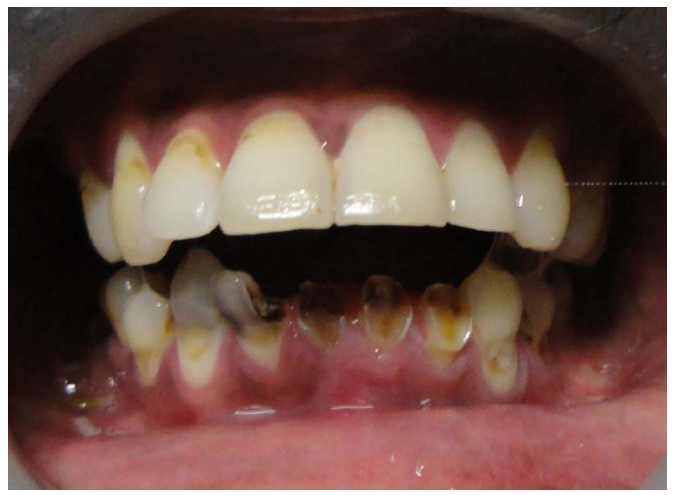

Figure 1 Intraoral view demonstrating maximum possible mouth opening.

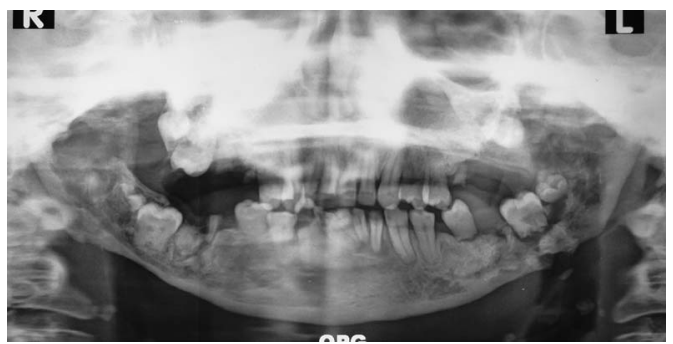

Figure 2 A dental panoramic radiograph showing features of altered dental development and osteoradionecrosis.

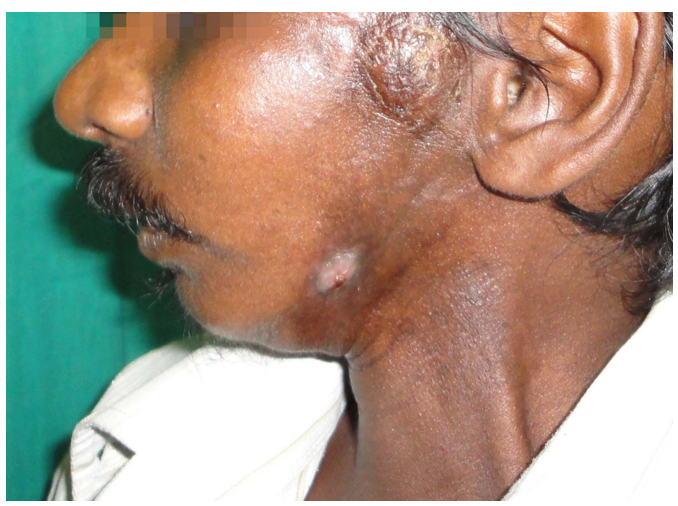

Figure 3 Left lateral view of the face showing the orofacial fistula, suppurative pre-auricular swelling and marked mandibular retrognathism.

Skeletal growth disturbance manifested as mandibular hypoplasia, causing skeletal class II malocclusion (figure 3 ).

- Multiple caries lesions (because of predisposition due to xerostomia, altered salivary characteristics and microbial flora, and constraints on oral hygiene measures due to pain, stomatodynia, etc).

\section{Learning points}

- The adverse effects of oncotherapy on the developing orofacial tissues may present long after the completion of active therapy.

- Information about these late effects should be given to the patient at the time of informed consent.

- Long term follow-up and proper oral hygiene measures (including the use of topical fluorides) in such cases is extremely important. 
Contributors BM, GA and BK were equally involved in the acquisition of data, preparation of the manuscript, critical revision of the content, and final approval of the version to be published.

\section{Competing interests None.}

Patient consent Obtained.

Provenance and peer review Not commissioned; externally peer reviewed.

\section{REFERENCES}

1 Goho C. Chemoradiation therapy: effect on dental development. Pediatr Dent 1993;15:6-12.

2 Vissink A, Jansma J, Spijkervet FK, et al. Oral sequelae of head and neck radiotherapy. Crit Rev Oral Biol Med 2003;14:199-212.

3 Otmani N. Oral and maxillofacial side effects of radiation therapy on children. J Can Dent Assoc 2007;73:257-61.

Copyright 2014 BMJ Publishing Group. All rights reserved. For permission to reuse any of this content visit http://group.bmj.com/group/rights-licensing/permissions.

BMJ Case Report Fellows may re-use this article for personal use and teaching without any further permission.

Become a Fellow of BMJ Case Reports today and you can:

- Submit as many cases as you like

- Enjoy fast sympathetic peer review and rapid publication of accepted articles

- Access all the published articles

- Re-use any of the published material for personal use and teaching without further permission

For information on Institutional Fellowships contact consortiasales@bmjgroup.com

Visit casereports.bmj.com for more articles like this and to become a Fellow 